\title{
Achievements and Contradictions in the Writing and Teaching of Cultural History in Hungary
}

ANDREA PETŐ

A book series bound in reddish brown leather can be found on the bookshelves not only of every historian but of every intellectual family in Hungary. From this statement it is obvious that this book series was a bestseller. Only after the books are removed from the shelf does it become clear whether they belong to the original series published between 1939 and 1942 or are reprints from 1990-91. This book series is the Cultural History of Hungary (Magyar müvelödéstörténet) by Sándor Domanovszky in five volumes. The series, which was a collective effort of the leading historians of the period, promised a "different perspective" on history-writing, as indicated by Domanovszky himself in the introduction:

"Focusing on the activity of the spirit which cannot be seen so sharply [...]. Instead of political life we would like to show the development of our culture to the reader $[\ldots]$. Everything that fits into the social cohabitation and its frame belongs here. Besides the spiritual and cultural, what kind of material will also be covered in the volumes? The changing character of the toiled soil, the composition of the inhabitants by nationality, the economy, the various branches of intellectual life, and the way of life of different strata of the society [...]."1

1 DomanovszKy 1990, Vol. 1. Introduction (all translations are mine unless otherwise indicated) p. 17. 
The book was illustrated with 2500 pictures and after underlining the backwardness and isolation of Hungarian historiography, it gave a synthesis of historical research during the interwar period written by leading specialists in the subfields. The result as a synthesis was limited even in the eye of Domanovszky, who in the introduction explained that the reason why so many collaborators contributed to the volume was due to the lack of basic primary research. $\mathrm{He}$ also noted the differences in the approaches of the individual contributors, who, however, were all experts in their own respective fields, which made their contributions reliable. The motto of the introduction: "The work should offer what we can offer at the present state of our knowledge" ${ }^{\text {"2 }}$ has serious epistemological consequences, which will be discussed later on in this article.

The success of the volume during World War II does not require much explanation, especially because it promised the familiar framework: "In this presentation the hero is replaced by the way of life, thinking, and creative activity of the mass of the nation." ${ }^{3}$ But the success of the reprint after the annus mirabilis of 1989 does, I believe, require an explanation, and I will return to this point.

In 2010, Domanovszky does not even earn a Wikipedia entry on Hungarian historians, while the zeal to publish summary volumes on cultural history without first defining the nature of cultural history is still alive and well. I will examine the urgent need for summary volumes below.

After the collapse of communism the first summary work on cultural history was edited by the ethnographer László Kósa and published in 1997. It was also published and reprinted in 2003, and since 1999 it has been available in English as Cultural History of Hungary (Magyar müvelódéstörténet) ${ }^{4}$ The book is on the required reading list for several university courses in Hungary. ${ }^{5}$

The editor, Kósa, defined the purpose of the collection as follows:

"The relationship between man and the natural world, the changes in and moulding of inanimate and animate nature, are the threads that run through our book from beginning to end: we analyse changes in the Hungarians' lifestyle and mentality, we examine their everyday experiences and their holidays through the ages, the surrounding material world, the ideologies that

2 ID.

3 ID.

4 KósA, 1999.

5 For an analysis of other encyclopedical publications after 1989 such as Pannon Chronicle and Hungarian Codex 1-5, see MonoK, 2006, p. 818-830. 
have shaped their lives and circumstances, and the habits and institutions of human communication and co-existence.”’

Parallel with this enterprise another important book series was begun: The Encyclopedia of Hungarian Cultural History (Magyar Müvelódéstörténeti Lexikon). ${ }^{7}$ For more than a decade 400 authors collected entries for this mega enterprise. The first volume was published in 2003, and as of 2010 eight volumes have appeared. This enterprise faced several difficulties and it proceeds very slowly due to financial problems and-as I will argue later on in this paper-due to conceptual issues which were not solved by listing the entries in alphabetical order within the strict format of an encyclopedia.

The Encyclopedia defined its aim as "to share with readers the history of literature, the history of art, the history of music, medicine, military history, monetary history, the history of everyday life, the history of nutrition, religion, the history of schooling etc. [my emphasis A. P.]."

It defined its scope as "the widest possible scope as defined by Hegel, not as history centered on events and politics. Hungarian as an adjective means Hungarian as the national framework of today's Hungary" ${ }^{9}$ In the introduction to the Encyclopedia of Hungarian Cultural History the editor refers to this approach: "We know that by identifying Hungarian with present day Hungary we have not solved several interrelated questions; instead we have gone around." 10

In this paper I present three different attempts to write the history of "culture" within a "Hungarian" national framework: one made during World War II, one seven years after the collapse of communism and one 17 years after the collapse of communism. I seek to reveal similarities and differences among these volumes in relation to their framing of the topic of cultural history. I do so by investigating three elements: imperial legacies, institutional developments and their relationship to interdisciplinarity.

6 KósA, 1999, original translation on p. 7.

7 Introduction in KőSZEGHY 2003, p. 8.

8 ID., p. 7

9 Kósa, 2003, I., p. 7.

10 KôSZEGHY, 2003, p. 2. 


\section{The period before World War II}

One element shared by the three series is immediately recognisable. All three volumes were produced in a national frame. Domanovszky even pointed out in his introduction that the only possible framework for historical analysis is the nation. The geographical focus has definitely switched from the imperial Greater Hungary (Kingdom of Hungary as a part of the Habsburg Empire), which was dominant during World War II, to Hungary within its present borders. Thus, those territories which historically belonged to the Kingdom of Hungary, are simply missing from the scope of current historical analyses.

What causes the amnesia and omission? During 50 years of communism the territories belonging to Hungary before the Trianon Peace Treaty of 1920 were taboo; they were doomed to oblivion. This is one of the reasons why the reprint of Domanovszky sold out so quickly in 1989. It promised knowledge about the lost homeland and filled a gap in historical knowledge caused by the quasinational framework of communist history-writing.

The question is: Did it sufficiently change the scope of historical analysis to permit an evaluation of the dramatic changes that were related to the collapse of the Kingdom of Hungary? Cooper argued that "empires produced (a) strong empire-centered imagination". ${ }^{11}$ People or citizens sought to make their way within the empire by means of collaboration and contestation, and this approach makes the people, the agents and the subjects invisible. In this paper I claim that the imperialist heritage poses a theoretical challenge to those who would write a new cultural history in Hungary.

But is there any change in the intellectual focus or, to rephrase the question, has the scope of writing cultural history changed at all?

Moving beyond the hopeless endeavour of defining cultural history, I examine instead the different influences and encounters that served to formulate the aims of the series. My aim is to answer the opening question: Why was Domanovszky's work a great success both during World War II and after the collapse of the communism?

The first issue to be examined is the issue of translation in a wider sense. The three volumes are all mentioned in this chapter under the heading of cultural history. However, they rather belong to the school of Kulturgeschichte-and to the subsection of Universalgeschichte, which includes everything but political and military history - than to new cultural history, and this partly explains the outstanding success of Domanovszky's work after 1989.

11 COOPER, 2005, p. 23. 
The confusion over terminology began in the early 1860 s when the specificity of Hungarian history was defined as a cultural mission (kultúrmisszió), which meant that for centuries the Hungarian nation had had to fight for its existence, leaving no time and space for embourgeoisement. Therefore the first generation of so-called cultural historians (müvelödéstörténészek) tended to focus on political history under the heading of cultural history. The term in Hungarian (müvelódéstörténet) means the history of education rather than the history of culture. For this reason, it can serve as a site for various intellectual approaches and political aspirations as far as the terminology is concerned. By the time the department of cultural history (müvelódéstörténet) was founded there was a need for methodological and theoretical innovation in the field in line with European developments. Instead of establishing special subsections of history, the post World War I period brought in spiritual history (szellemtörténet). As the Bálint Hóman declared: "Spiritual history, or to use a synonym cultural history (múvelödéstörténet), is conceptualised as the really right one."12

The Hungarian pioneers of cultural history (kultúrtörténet), Arnold Hauser and Karl Polanyi, had already emigrated from Hungary when the Domanovszky series was published in Budapest; their works remained unreferenced in these books. Domanovszky's work arose in the post-1919 period. For those who are unfamiliar with Hungarian history, it is worth noting that the year 1919, which marked the end of two revolutions in Hungary, saw the first exodus of leftist, critical intellectuals from Hungary to Vienna and Berlin, many of whom later moved to London and to the United States. The approach to culture of such historians as Polanyi or Hauser, who before 1918 belonged to the progressive circle Huszadik Század (Twentieth Century), was very different from that of Domanovszky, who headed the department of cultural history at Budapest University.

The other school of thought challenging the spiritualised version of cultural history, was economic history. Hungary's economic historians also considered their approach in universalistic terms as "the history of the nation", as was pointed out by Alajos Paikert (1866-1948), editor of Gazdaságtörténeti Szemle (Review of Economic History, 1894-1906), in his introductory comments to the first issue of the journal.

In his work, Domanovszky ignored sociological, psychological and economic analyses, which were regarded as suspiciously leftist in what was a conservative-rightist era. He followed the German type of Geistesgeschichte in his Hungarian Cultural History. Hungary lost its national dominance in the Carpathian

12 Quoted without a reference in VÁRKONYI, 1970, p. 147. 
basin after 1920, but the official cultural politics of the interwar period retained a kind of neo-nationalism in the form of cultural supremacy (kultúrfölény) dangerously resembling cultural mission (kultúrmisszió). Historicising that imagined realm, writing about the lost territories was a subtle form of domination. The strong empire-centered imagination created culture as an imagined form of domination. This explains in part the success of the book then and also in 1989 when the ideological censorship promoting Soviet domination under the cover of internationalism collapsed. This led to the nostalgia for summary volumes published during the interwar Horthy era: the old encyclopedias became popular in the search for historical roots and as a means of reconstructing intellectual connections with the Horthy era that had been broken under communism. This revival of an imagined historical tradition forms the basis for new conservative history-writing in Hungary.

Domanovszky's summary work on Hungarian cultural history has been criticised for its lack of "coherence".

One of the first historians to criticise the endeavour during World War II was Bálint Hóman, a historian and a minister of culture (1932-42), who was sentenced to life imprisonment by the people's tribunals after World War II. He criticised the book series for "questioning coherence and continuity". ${ }^{13} \mathrm{He}$ also labeled cultural history as an "appendix to history" ${ }^{14}$ History for Hóman was political history; wie es gewesen war. Moreover, for him the loss of national supremacy was just temporary, and as a powerful politician and intellectual he did his best to demonstrate this was so by supporting German war efforts. In his view concrete political and military action was needed, not "strong empirecentered imagination".

Hóman's criticism was paradoxically echoed by the doyen of Hungarian cultural studies, Kosáry, who was imprisoned by the communist regime after 1956. In 1983 he argued that Domanovszky's five-volume series "lacked any sign of internal coherence". ${ }^{15}$ But this "coherence" was just different to one from that demanded by Hóman. For Hóman it was simply not the right history of culture, in view of its descriptive and positivist character and the fact that it was not "spiritual" enough.

13 Hóman, 1938, p. 33.

14 ID.

15 KoSÁry, 1983, P. 16. 


\section{During communism}

So is there any chance of achieving internal coherence in the case of cultural history? What do these constant demands for coherence tell us about the place of cultural history-writing in Hungary? How can or could cultural history move away from the "history of etceteras" as defined in the Encyclopedia of Hungarian Cultural History? Why is new cultural history missing from Hungarian historiography, even though micro-history, cultural anthropology and other new approaches are present in history-writing? In order to answer these questions, we need to briefly examine the institutional developments of cultural historywriting in Hungary.

It is no surprise that the department of cultural history led by Domanovszky and founded in 1898 was closed after the post-war communist takeover. The superiority of structures and class as explanatory categories left no space for the Geistesgeschichte or cultural history, which was also discredited politically because of its strong ideological ties to the interwar Horthy regime. Culture was defined only as a superstructure in relation to the economically determined social basis.

The Cold War quarantine of history-writing in Hungary, a development that could also be observed in other countries on the eastern side of the Iron Curtain, effectively prevented developments or experiments in history-writing. Historians that did not fit into the Marxist framework worked at the Institute of History or in various regional archives. Paradoxically, it was the Institute of History that was commissioned with writing what was supposed to be a Marxist summary history of Hungary in ten volumes, the so-called missing synthesis of Hungarian history. ${ }^{16}$ At the beginning of the endeavour a debate started about how to define culture.

This debate signaled that, as the Kadar regime relinquished its hold on society, the unquestionable dominance of Marxist history-writing (including economic history as the main genre) was nearly over. Those who did not challenge the major ideological cornerstones of the Kadar regime, which by chance were all connected to the history of $20^{\text {th }}$ century $(1919,1945$, and 1956), were permitted to experiment with certain new approaches to history-writing. Kosáry, for example, openly challenged the dominant Marxist idea of base and superstructure, the division between material and spiritual, and he advocated the concept

16 The first nine volumes have been published; the tenth on post-1945 history is yet to be published. These volumes are still used as the only available modern synthesis in education and research. 
of "totalistic history" ${ }^{17}$ Kosáry during the war and immediately after World War II was educated in France, and he was a follower of the Annales School. He believed in long dureé, the structures and patterns that shape and influence history, so if we know these we will know History. The Annales had a connection with Hungarian historians from 1966; conferences and workshops were organised. The major works by Chaunu and Braudel were translated into Hungarian within a few years of their publication in French. For these historians the focus of study was culture, as a single and unified element.

The first challenge to the Marxist historical cannon came when some historians tried to integrate the works of Annales, which, as I have already argued, fitted into the existing positivist framework. The debate, published in the main journals of the historical profession, Századok, in 1970 and in Történelmi Szemle in 1974, sketched the various approaches of Hungarian historians to the concept of culture. This debate had an enormous impact on the development of Hungarian history-writing: during the later years of the Kádár era, leading historians were given the chance to define the subject matter of history and the place of culture therein. Reading this debate today, one notices how the different concepts and trends of Annales and the German school of Kulturgeschichte were mentioned and used as analytical categories, even while the Marxist dogmas and taboos continued to be cleverly acknowledged. Braudel, Mandrou, Chaunu and their main works were mentioned along with early versions of discourse analysis, while, of course, the authors had to praise Lenin's concept of culture. ${ }^{18}$

Cultural history (müvelódéstörténet) is defined as social history, as the history of mentality, and as an appendix to economic history. Niederhauser, employing a pragmatic approach, defined it as the material culture described by Domanovszky combined with the writing and editorial techniques of Huizinga and Burckhardt and supplemented with some interesting, catchy stories that have no real "scientific" value. ${ }^{19}$

Péter Hanák, one of the authors of the cultural history sections of the tenvolume History of Hungary and an active participant in the debate,${ }^{20}$ launched an attack on the traditional, positivist and vulgar Marxist frameworks, while also challenging the long-entrenched divisions of political, ethnic, social and

17 KOSÁRY, 1974, p. 440.

18 In some works the author, for example Braudel, is not mentioned. Instead, their works and ideas are presented as a way forward. MAKKAI, 1974, p. 432.

19 NiEDERHAUSER, 1974, p. 420.

20 HANÁK, 1974, p. 447-450. 
economic history. ${ }^{21}$ Having been influenced by Carl Schorske, he re-introduced cultural history (kultúrtörténet). He used culture as a set of symbols and as a constitutive element of people's understanding of the surrounding world. Hanák explained his growing interest in cultural studies as a response to the unsatisfactory explanatory models of the dominant political history: he looked for the singular and unrepeatable everyday practices of daily life.

The second institutional challenge occurred only in the early 1980s. In 1981, the Hungarian Academy of Sciences established the Committee on Cultural History (Müvelódéstörténet), whose task was to coordinate research on the middle Ages, renaissance and baroque studies. Béla Köpeczi, a scholar of $18^{\text {th }}$ century French literature, was appointed as the committee's chair. In 1982, Köpeczi became minister of culture, and thereafter the committee received all possible help (and intellectual shelter) from the communist authorities. His presence helped to institutionalise the committee's work within the Hungarian Academy of Sciences.

The time was ripe for the reconditioning of a department of cultural history. In 1981, the first head of the new Department of Cultural History at ELTE in Budapest, Béla G. Németh, defined the department's mission as the history of ideas, the history of institutions and the history of everyday life. For Németh "cultural history is a general historical science, which reaches out to all aspects of life through the tools of defining and underlining historicity". ${ }^{22}$ After a long ban from teaching activity Péter Hanák was also hired as a professor in the department.

Summarising developments during communism, we can identify three tendencies that co-existed until 1989: the narrow application of the history of ideas; an inability to respond to the interdisciplinary challenge posed by new social scientific methods; and the intellectual legacy of Domanovszky, where cultural history was viewed as "general history". We may now be reluctant to remember 1989 as the annus mirabilis, but at the time there were several factors that made us hope for a paradigm shift in Hungarian history-writing: the end of direct ideological censorship (which, as we have seen, was already crumbling); the increasing importance of international exchanges; and the foundation of new higher educational institutions. Let us see whether and how these factors impacted the development of cultural history.

21 See more on this in PETő/SZAPOR, 2007, p. 160-166.

22 Németh quoted in DobsZAY/FónAGY, 2003, p. 407. Original quote in NÉMETH, 1998, p. 39. 


\section{The post-1989 period with new attempts and failed interdisciplinarity}

In the mid-1980s, together with the ideological opening, the methodologies of economic history, historical demography and sociology embraced by historians paid dividends in investigations into the roots of economic and social modernisation, including historical studies of gender history. ${ }^{23}$ In 1987 the new generation of historians - mostly social historians, gathered to form the István Hajnal Circle - in opposition to the mainstream academics of the Hungarian Historical Association, founded in 1867 . Their aim was to scrutinise the discourses of political history that had been used exclusively to write about history and to create their own professional and existential legitimacy. The arguments they put forward were very similar to the arguments cited by Domanovszky in his introduction to the five-volume series. Let us examine the consequences of social history becoming the dominant framework for a renewal of Hungarian history-writing after 1989 and as a force opposing the exclusive focus on political history and weakening what remained of the Marxist framework.

The Hajnal Circle sought to establish social history as an alternative to all other approaches to history-writing. However, this attempt led to marginalisation and localisation. One of the main intellectual and professional achievements of the group was the publication of a state-of-the-art volume entitled Introduction to Social History in 2003. ${ }^{24}$ Tellingly, this introductory handbook, designed for use by university students, divides the various approaches to history-writing into old and new schools. Branches of history-writing such as urban history, religious history, economic history, historical demography, historical geography, political history and the history of culture (müvelödéstörténet) were classified as old schools of writing history. Meanwhile, among the new schools, we find micro-history, historical anthropology, the linguistic turn, the history of mentality, psychohistory and gender. With this categorisation cultural history as a school of thought was subordinated to the German Ideengeschichte school. In the chapter on cultural history as "old history" the term itself was translated using such synonyms as cultural studies, the history of culture, Kulturgeschichte, and Historische Kulturforschung. ${ }^{25}$ The confusion about the translation explains why there is a reluctance to take a position on the definition of cultural history and its relevance for Hungarian history-writing in the new millennium. The au-

23 Peтő, 2003.

24 ZsOMBOR/KOVÁCS, 2003.

25 DobsZay/FónAgy, 2003, p. 387-413. 
thors of the chapter on cultural history even formulated a critical counter argument against cultural history, one that strangely echoes the criticisms of Hóman and Kosáry. They characterised it as "unprofessional, driven by interests and extremes, lacking a methodological and theoretical zeal of its own, and excessively heterogeneous". ${ }^{26}$

Since heterogeneity was mentioned once again as a weakness, perhaps we should seek to explain the old-new attachment to homogeneous history-writing. Why did this attachment resurface after 1989?

The complex relationship of the historical profession to interdisciplinary approaches also influences the status of cultural history in Hungary. The social sciences and the humanities are still sharply divided along institutional lines. Cultural studies are mostly the domain of literary scholars, and this influences the chosen subject matter. For instance, the editor in chief of the Encyclopedia of Hungarian Cultural History is a literary scholar, and so the series focuses on the Middle Ages and the Early Modern period. Their emphasis upon micro studies and the publication of sources leaves no room for theorizing. This position is shared by the majority of Hungarian historians.

In this paper I claim that the discontinuity in the Hungarian historical canon has been falsely attributed to $1945 .{ }^{27}$ The Hungarian historical canon was not even challenged by the modernist approaches after 1989 and it is resistant to modernist thinking, including the modernism that developed from the ideas of Polanyi and Hauser. My argument is that this is due to the empire-centered imagination, which has remained unchallenged ever since 1919. I also identify two additional factors: the emergence of social history as the dominant paradigm and the specificities of transatlantic connections.

Before World War II the new historical method of inquiry was the statistical method, (economic history) and this only strengthened the positivist base of history-writing. After 1945 statistical (economic) history formed a poisonous alliance with Marxist economic history-writing, which was regarded as the only explanatory framework for historical analysis. It is no accident that Annales was allowed, if not encouraged to establish a foothold in Hungary under communism. So in this sense Marxist historiography never challenged history's claim to objectivity as it was framed by Ranke. Indeed, the claim was strengthened by the (illusory) significance Marxist historians attached to scientific materialism, which produced ready-made explanations for all sorts of events and tendencies in the past. In the communist era, history not only acted to create and sustain

26 ID., p. 396.

27 Petó, 2011, p. 67-75. 
national identity - as it had done ever since the emergence of the nation-statesbut also served as a rationale for class struggle. ${ }^{28}$

During communism historians of the medieval and early modern period quietly joined the Annales-influenced European mainstream, publishing works on witches and female saints. ${ }^{29}$ The other intellectual influence was the German ethnographical method. Before 1989, both major European historiographies established a presence behind the Iron Curtain means of academic exchanges and scholarships granted to young and senior researchers. This had intellectual consequences in 1989. These approaches to historiography, unlike the Anglo-Saxon schools, tended to look at everyday life and the life of small communities; the study of which remained untouched by culture as a symbolic system. Therefore it is no accident that social history emerged as a new field after 1989.

After 1989 both Germany and France, for different reasons, attributed secondary importance to history-writing in Central Europe. This contrasts with the increasing involvement of the United States in the region. German and French interest was revived with EU enlargement and the growing importance of the European Union as a potential site of resistance to American unilateralism. However, by the time the intellectual influence of the US academia increased in Hungary and in other Central European countries, the avant-garde cutting edge works in history were no longer produced in the field of Cultural History.

A paradigmatic change in history-writing was expected to occur with the emergence of a new generation of historians, trained in the second half of the 1980s. But these young historians did not identify themselves with Cultural History, which at Budapest University became a bastion of the history of ideas, especially after the departure of Péter Hanák. Instead they identified with other new branches such as historical anthropology or social history.

The removal of the ideological censorship of the communist party and the foundation of new universities opened up space for new sections within history departments, including social history and cultural anthropology. In Pécs (in 2000) and in Miskolc (1995) departments of cultural history were formed. These new departments produced large numbers of graduates until the introduction of the Bologna Process following Hungary's accession to the European Union. The Bologna Process, a reduction in state support for higher education, and a decrease in student numbers for demographic reasons, served to weaken the hegemony of the mammoth history departments whose institutional structure had remained unchanged since the $19^{\text {th }}$ century.

28 GYÁNI, 1993, p. 893-915.

29 Just to list some early works: Sz. JónÁs, 1986; KLANICZAY et. al., 1989. 
It is no accident that at the most inventive institution, the CEU, where American influences were the strongest, the History Department (headed by Péter Hanák from 1991) introduced courses on cultural history and hosted guest speakers from Greenblatt to Davis. Today the CEU offers MA and PhD courses in this field, but they are all in English.

The limited institutionalisation of cultural history is partly due to the lack of translated works in the broadest sense. Unlike the major works of the Annales tradition, which were translated into Hungarian in the 1970s or 1980s, few more recent theoretical works by foreign historians are available in Hungarian. Standard university textbooks such as Introduction to Social History, which summarise international developments in historiography, have only recently appeared. The authors, who might be considered founding members of cultural history, are categorised under historical anthropology in Hungary, which is very much a marginalised subject both intellectually and institutionally. A modernisation of the language of the historical profession is still awaited.

\section{Conclusions}

Alon Confino and Allan Megill pointed out how memory became the leading term in new cultural history at the end of $1990 \mathrm{~s} .{ }^{30}$ Hungarian historiography was unprepared for this paradigm shift, owing to the imperial character of historywriting, a lack of openness to interdisciplinary perspectives, and the traditional structure of higher education. The positivist epistemological basis of history as a science has remained fundamentally unchanged in Hungary since 1989. Just as Hóman and Kosáry criticised the five volumes edited by Domanovszky, so we can make the important point that cultural history does not have a relevant intellectual repertoire and is resistant to interdisciplinarity.

These factors explain why cultural history, as it is written today in Hungary and presented in the third series analysed above, remains in the same paradigm: Kulturgeschichte. Of course, I do not want to set up hierarchies between the different approaches. My intention is to highlight the dangerous connections (liaison dangereuse) between uncritical versions of Marxist history-writing and positivist history-writing. Loomba argued that "Colonialism is not just something that happens from outside a country or a people, not just something that operates with the collusion of forces inside, but a version of it can be duplicated

30 Confino, 1997, p. 1386. 
from within. ${ }^{\prime 31}$ I argue that the relationship between the colonised and the coloniser, this strategic essentialism, is reflected in the rhetoric of history-writing, and we can trace this phenomenon by examining how new cultural history is written or rather not written in Hungary today. New cultural history that focuses on the individual as an agent of change is a doomed enterprise in this postcolonial framework.

\section{Literature}

Confino, Allon, Collective Memory and Cultural History? Problems of Method, in: American Historical Review 102, 4 (1997), p. 1386-1403.

CoOPer, Frederick, Colonialism in Question. Theory, Knowledge, History. Berkeley et al. 2005.

DobSZAY, TAMÁs/Fónagy, ZoLTÁn, Múvelődéstörténet, in: Bevezetés a társadalomtörténetbe, ed. by BóDY ZsOMBOR/JÓZSEF Ö. KovÁcs, Budapest 2003, p. 387-409.

DoMANOVSZKY, SÁNDOR, Magyar múvelődéstörténet, I-V, Budapest 1990-1991.

GYÁNI, GÁBOR, Political Uses of Tradition in Post Communist East Central Europe, in: Social Research 60, 4 (1993), p. 893-915.

HANÁK, PÉTER, A kultúrtörténet problémái, in: Történelmi Szemle 3-4 (1974), p. 447- 450 .

HómAn, BÁLINT, A történelem útja, in: Történetírás és forráskritika, Budapest 1938, p. 9-45.

KLANICZAY, GÁBOR et al. (eds.), Magyarországi boszorkányperek, Budapest 1989.

KósA, LÁszló (ed.), A Cultural History of Hungary: from the Beginnings to the Eighteenth Century, Budapest 1999 (Hungarian editions in 1998, 2003, 2005).

KosÁry, Domokos, A múvelődéstörténet helye a szintézisben, in: Történelmi Szemle 3-4 (1974), p. 438- 446.

ID., Múvelódés a 18. századi Magyarországon, Budapest 1983.

KôSZEGHY, PÉTER (ed.), Magyar Múvelődéstörténeti Lexikon, Budapest 2003. LOOMBA, ANiA, Colonialism. Postcolonialism, London 1998.

MAKKAI, LÁsZLÓ, Mûvelôdéstörténet, mint értékrendszerek története, in: Történelmi Szemle 3-4 (1974), p. 429-437.

31 Loomba, 1998, p. 12. 
MonoK, IsTVÁN, A múvelődéstörténeti kutatásokról, in: Magyar Tudomány 7 (2006), p. 818-830.

NÉMETH, G. BÉLA, Múvelődéstörténet, in: Múvelődéstörténet. Tanulmányok és kronológia a magyar nép múvelődésének, életmódjának és mentalitásának történetéből I-II, ed. by B. GelencSÉr KATALIN, Budapest 1998, p. 39-43.

Niederhauser, Emil, A kultúrtörténet kérdéséhez, in: Történelmi Szemle 3-4 (1974), p. 420-429.

Pető, ANDREA, Hungarian Women in Politics 1945-1951 (East European Monographs Series), New York 2003.

ID., New Differences? Competing Canonization of History of World War II, in: Überbringen-Überformen-Überblenden. Theorietransfer im 20. Jahrhundert, ed. by DieTLIND HÜCHTKER/ALFrun KLIEMS, Köln et al. 2011, p. 67-75. Petó, AndRea/SzAPOR, Judit, The State of Women's and Gender History in Eastern Europe: The Case of Hungary, in: Journal of Women's History 19, 1 (2007) p. 160-166.

R. VÁRKONYI, ÁGNES, Múvelődéstörténeti törekvések az európai és hazai polgári történetírásban in: Vita a múvelődéstörténet kérdéséről, in: Századok 1 (1970), p. 136-148.

Sz. JóNÁs, ILONA, Árpádházi Szent Erzsébet, Budapest 1986.

ZsOMBER, BóDY/KovÁCs JoseF Ö., (eds.), Bevezetés a társadalom törté net be, Budapest 2003. 
